\title{
A Phase 1 dose-escalation study of disulfiram and copper gluconate in patients with advanced solid tumors involving the liver using S-glutathionylation as a biomarker
}

Kristen C. Kelley ${ }^{1}$, Kenneth F. Grossman², Mary Brittain-Blankenship ${ }^{1}$, Kelli M. Thorne ${ }^{3}$, Wallace L. Akerley², Moises C. Terrazas ${ }^{4}$, Ken M. Kosak ${ }^{4}$, Kenneth M. Boucher', Saundra S. Buys ${ }^{2}$, Kimberly A. McGregor ${ }^{2}$, Theresa L. Werner', Neeraj Agarwal' ${ }^{2}$, John R. Weis ${ }^{2}$, Sunil Sharma², John H. Ward², Thomas P. Kennedy ${ }^{5}$, Douglas W. Sborov ${ }^{4}$ and Paul J. Shami ${ }^{4^{*}}$

\begin{abstract}
Background: Disulfiram and metals inactivate key oncoproteins resulting in anti-neoplastic activity. The goal of this study was to determine the maximum tolerated dose of copper when administered with disulfiram in patients with advanced solid tumors and liver involvement.

Methods: Disulfiram $250 \mathrm{mg}$ was administered daily in 28-day cycles. Four doses of copper gluconate were tested $(2,4,6$, and $8 \mathrm{mg}$ of elemental copper) in a standard $3+3$ dose escalation design. Patients were evaluated for dose limiting toxicities and response. Protein S-glutathionylation was evaluated as a pharmacodynamic marker.

Results: Twenty-one patients were enrolled and 16 patients were evaluable for dose limiting toxicities. Among the 21 patients, there was a median of 4 lines of prior chemotherapy. Five Grade 3 toxicities were observed (anorexia, elevated aspartate aminotransferase or AST, elevated alkaline phosphatase, fever, and fatigue). Response data was available for 15 patients. Four patients had stable disease with the longest duration of disease control being 116 days. The median duration of treatment for evaluable patients was 55 days (range 28-124). Reasons for discontinuation included functional decline, disease progression, and disease-associated death. Increased Sglutathionylation of serum proteins was observed with treatment.

\footnotetext{
* Correspondence: paul.shami@utah.edu

${ }^{4}$ Division of Hematology and Hematologic Malignancies, Department of Internal Medicine, Huntsman Cancer Institute, University of Utah, 2000 Circle of Hope, Salt Lake City, Utah, USA

Full list of author information is available at the end of the article
}

C C The Author(s). 2021 Open Access This article is licensed under a Creative Commons Attribution 4.0 International License, which permits use, sharing, adaptation, distribution and reproduction in any medium or format, as long as you give appropriate credit to the original author(s) and the source, provide a link to the Creative Commons licence, and indicate if changes were made. The images or other third party material in this article are included in the article's Creative Commons licence, unless indicated otherwise in a credit line to the material. If material is not included in the article's Creative Commons licence and your intended use is not permitted by statutory regulation or exceeds the permitted use, you will need to obtain permission directly from the copyright holder. To view a copy of this licence, visit http://creativecommons.org/licenses/by/4.0/ The Creative Commons Public Domain Dedication waiver (http://creativecommons.org/publicdomain/zero/1.0/) applies to the data made available in this article, unless otherwise stated in a credit line to the data. 


\begin{abstract}
(Continued from previous page)
Conclusion: Disulfiram $250 \mathrm{mg}$ daily with copper gluconate (8 $\mathrm{mg}$ of elemental copper) was well-tolerated in patients with solid tumors involving the liver and was not associated with dose limiting toxicities. While temporary disease stabilization was noted in some patients, no objective responses were observed. Treatment was associated with an increase in S-glutathionylation suggesting that this combination could exert a suppressive effect on cellular growth and protein function.
\end{abstract}

Trial registration: NCT00742911, first posted 28/08/2008.

Keywords: Disulfiram, Copper gluconate, S-glutathionylation

\section{Background}

Disulfiram is a drug best known for the treatment of alcoholism. Its anti-cancer properties were first reported in the early 1960s [1]. As a lipophilic dithiocarbamate, disulfiram crosses the cell membrane and complexes with metal ions [2]. These complexes disrupt vital signaling pathways through the formation of reactive oxygen species [3-10], interference with DNA expression $[8,11-14]$, anti-proteasome activity [15-22], anti-angiogenesis properties [10, 23, 24], and disruption of mitochondrial membrane permeability and polarization $[25,26]$. Apoptosis in cancer cells is induced [14, 16, 20-22, 27-29] via activation of ERK and JNK pathways and p38 stress-activated protein kinases [8, 30, 31]. Copper supplementation of growth media increases pro-apoptotic [29] and antiproteosome [16] activities of disulfiram to a greater extent than other metals.

Disulfiram-metal complexes can also re-sensitize tumor cells to chemotherapy by inhibiting the multidrug resistance P-glycoprotein [32-34] or acetaldehyde dehydrogenase, which can be increased in cancer cells [35]. Re-sensitization to 5-fluorouracil [36], cisplatin [37], gemcitabine [38], doxorubicin [39], and temozolomide [40] has been observed along with possible potentiation of cytotoxicity [38, 40, 41].

This Phase 1 trial was designed to determine the safety of disulfiram when combined with copper gluconate in treating patients with refractory malignancies metastatic to the liver. Early phase clinical trials of disulfiram-metal combinations have demonstrated a favorable safety profile across a variety of doses and schedules (Supplementary Table 1) [42-46]. The liver is a common site of metastasis for a variety of solid tumors, most commonly adenocarcinomas of the colon, pancreas, or breast [47]. Hepatic metastases portend a poor prognosis and there is a need for novel therapies to improve outcomes in this population. Hepatic antineoplastic activity is supported by a report of a patient with stage IV ocular melanoma with hepatic metastases who obtained a clinical remission for 53 months after treatment with zinc gluconate and disulfiram [11].

\section{Methods}

\section{Patient selection}

Patients 18 years of age or older with solid tumors, hepatic metastases, and an expected survival of at least 3 months were eligible. Patients were to have exhausted or refused standard therapies for their disease. Patients had to refrain from alcoholic beverages while on study and could not be receiving other chemotherapy while enrolled. Baseline aspartate aminotransferase (AST) and alanine transaminase (ALT) levels less than 5 times the upper limit of normal, normal serum copper levels, and serum ceruloplasmin greater than $17 \mathrm{mg} / \mathrm{dL}$ were required. Of note, the trial was amended to change the eligibility criteria for baseline AST and ALT from less than 2.5 times the upper limit of normal to less than 5 times the upper limit of normal. With this being a trial that involves liver metastasis, it is expected that patients will have elevated liver enzymes in this setting. As a result of the change in eligibility, the dose limiting toxicity (DLT) criteria were amended at the same time to exclude Grade 3 or 4 liver function abnormalities as DLT if the patient had Grade 3 or 4 liver function abnormalities at baseline. These patients were closely monitored to see if any trend could be seen relating to study drug administration. This amendment did not impact any previous patient enrollments.

Exclusion criteria included active liver disease other than metastatic cancer, Eastern Cooperative Oncology Group (ECOG) performance status of 3 or 4, pregnant or nursing women, and women of childbearing potential who were not using contraception. Patients with a family history of Wilson's disease or hemochromatosis were excluded as were those taking medications metabolized by cytochrome P450 2E1 or those whose metabolism is likely influenced by disulfiram.

\section{Study design and treatment}

Patients were enrolled between 2008 and 2011 at the University of Utah Huntsman Cancer Institute. The study was conducted under Investigational New Drug (IND) \#100,937 and approved by the University of Utah Institutional Review Board. The study was designed as a standard $3+3$ dose escalation to determine the 
maximum tolerated dose (MTD) or maximum administered dose (MAD) of copper gluconate with a fixed dose of disulfiram. Toxicities were Graded according to the Cancer Therapy Evaluation Program Common Terminology Criteria for Adverse Events Version 3. To be evaluable for dose-limiting toxicity (DLT) assessment, patients were required to complete 28 days of treatment. A DLT was defined as Grade 3 or higher nausea, persistent Grade 4 neutropenia, febrile neutropenia, Grade 4 thrombocytopenia or Grade 3 thrombocytopenia with bleeding or transfusion needs, Grade 4 anemia, or any Grade 4 non-hematologic toxicity.

Patients were assigned to one of 4 dose cohorts of copper gluconate with an $8 \mathrm{mg}$ maximum dose of elemental copper (Table 1 ) together with disulfiram at a fixed dose of $250 \mathrm{mg}$ orally per day. Disulfiram was prescribed from commercial sources. Copper gluconate was obtained from Twin Labs (American Fork, UT). Disulfiram was taken with the evening meal separate from copper gluconate in the morning to minimize gastrointestinal toxicity. 28-day treatment cycles continued until toxicity or disease progression. All patients, including those who discontinue protocol therapy early, were followed for response until progression and for survival for up to 2 years from the date of registration.

\section{Outcomes}

The primary outcome was the safety, tolerability, and MTD of disulfiram and copper gluconate in patients with hepatic metastases. Secondary outcomes included treatment response using RECIST v.1.0 criteria (data analysis occurred prior to RECIST v. 1.1) and a qualitative assessment of the induction of $S$-glutathionylation in proteins of circulating leukocytes. Treatment response was assessed with measurement of tumor markers with each cycle and CT scans of the chest, abdomen, and pelvis which were obtained after every two cycles of treatment to evaluate response.

\section{Statistical analysis}

Statistical analysis was descriptive as the power of a $3+$ 3 study to accurately determine the real rate of toxicity at a given dose is limited. Response rates and correlative studies likewise involved small sample numbers of

Table 1 Dose escalation scheme

\begin{tabular}{lll}
\hline Cohort & Copper Gluconate & Disulfiram \\
\hline 1 & $2 \mathrm{mg}^{\mathrm{a}}$ & $250 \mathrm{mg}$ \\
2 & $4 \mathrm{mg}$ & \\
3 & $6 \mathrm{mg}$ & \\
4 & $8 \mathrm{mg}$ & \\
\hline
\end{tabular}

${ }^{\mathrm{a}} \mathrm{mg}$ milligrams of elemental copper different malignancies and thus these outcome measures are also descriptive in nature.

\section{Pharmacodynamics}

We hypothesized that this combination would inactivate proteins important for malignant cell growth through $S$ glutathionylation of cysteine residues on proteins. $S$-glutathionylation assays were performed on plasma proteins at baseline and on day 8 of treatment. Plasma proteins were isolated from the peripheral blood and $30 \mathrm{mcg}$ of protein were separated by SDS-PAGE under nonreducing conditions. Following transfer, $S$-glutathionylation levels were evaluated using Western blotting procedures with primary anti-glutathione mouse monoclonal antibody (ViroGen, Watertown, MA). Loading control was performed with a mouse anti-human IgG (SigmaAldrich, St. Louis, MO).

\section{Results}

\section{Patients}

Twenty-one patients were enrolled and treated. Sixteen were evaluable for DLTs. Of those, 11 were women. Thirteen patients were Caucasian, two were Native American/Alaska Native, and 1 was Asian. Five patients were not evaluable because they received less than 28 days of treatment (Supplementary Table 2). The median age of the evaluable patients was 58 (range 27-81). Tumor types included pancreatic adenocarcinoma, colorectal adenocarcinoma, non-small cell lung carcinoma, cutaneous and ocular melanoma, thymic carcinoma, and breast carcinoma. The median number of prior lines of treatment was 4 (range $0-12$ ) with 11 of the 16 evaluable patients also having received prior radiation (Table 2).

\section{Safety}

No DLTs were observed. Overall, there were 53 adverse events felt to be possibly, probably, or definitely related to study treatment in the evaluable patients. These are summarized in Table 3 . The most common adverse events were abnormalities in liver function tests, fatigue, nausea, dysgeusia, and vomiting. The majority of events $(n=30)$ occurred in Cohort 4 including three of the 5 Grade 3 events. These included elevated AST and alkaline phosphatase, fatigue, anorexia, and fever. There were no Grade 4 or 5 events attributed to study treatment.

In Cohort 1, three of the 7 patients enrolled were evaluable. Reasons for lack of evaluation included medication non-adherence in 1 patient and rapid disease progression in 3 patients.

Three patients in Cohort 2 were evaluable. Two Grade 3 adverse events were recorded that were possibly related to the study treatment and included elevated 
Table 2 Characteristics of evaluable patients

\begin{tabular}{|c|c|c|c|c|c|c|}
\hline ID & Cohort & Age & Sex & Race $^{a}$ & Primary Tumor Type & Prior Treatments \\
\hline 1 & 1 & 63 & M & NA & Pancreas & 3 \\
\hline 2 & & 34 & M & NA & Colon & 6 \\
\hline 3 & & 62 & $F$ & $\mathrm{C}$ & Lung & 5 \\
\hline 4 & 2 & 57 & $\mathbf{F}$ & $\mathrm{C}$ & Melanoma (Ocular) & 1 \\
\hline 5 & & 27 & M & $\mathrm{C}$ & Thymic & 3 \\
\hline 6 & & 44 & $\mathrm{~F}$ & $\mathrm{C}$ & Breast & 12 \\
\hline 7 & 3 & 66 & $\mathrm{~F}$ & $\mathrm{C}$ & Melanoma (Cutaneous) & 1 \\
\hline 8 & & 70 & $\mathrm{~F}$ & $\mathrm{C}$ & Melanoma (Cutaneous) & 1 \\
\hline 9 & & 70 & M & $\mathrm{C}$ & Melanoma (Cutaneous) & 1 \\
\hline 10 & 4 & 43 & $\mathrm{~F}$ & $\mathrm{C}$ & Breast & 7 \\
\hline 11 & & 59 & $F$ & $\mathrm{C}$ & Melanoma (Ocular) & 0 \\
\hline 12 & & 57 & M & $\mathrm{C}$ & Melanoma (Cutaneous) & 5 \\
\hline 13 & & 81 & $F$ & $\mathrm{C}$ & Melanoma (Ocular) & 0 \\
\hline 14 & & 57 & $\mathbf{F}$ & $\mathrm{C}$ & Breast & 6 \\
\hline 15 & & 61 & $F$ & A & Breast & 9 \\
\hline 16 & & 53 & $\mathbf{F}$ & $\mathrm{C}$ & Breast & 6 \\
\hline
\end{tabular}

${ }^{a}$ C Caucasian, NA Native American or Alaska Native, A Asian

${ }^{\mathrm{b}}$ Including chemotherapy and endocrine therapy. ID identification, $M$ male, $F$ female

Table 3 Common toxicities attributable to study treatment in evaluable patients

\begin{tabular}{|c|c|c|c|c|}
\hline Event & Grade 1 & Grade 2 & Grade 3 & Total \\
\hline Elevated AST & 3 & 2 & 1 & 6 \\
\hline Fatigue & 4 & 1 & 1 & 6 \\
\hline Elevated ALT & 3 & 1 & 0 & 4 \\
\hline Nausea & 3 & 1 & 0 & 4 \\
\hline Taste changes & 2 & 1 & 0 & 3 \\
\hline Vomiting & 2 & 1 & 0 & 3 \\
\hline Dizziness & 3 & 0 & 0 & 3 \\
\hline Elevated alkaline phosphatase & 1 & 1 & 1 & 3 \\
\hline Anorexia & 1 & 0 & 1 & 2 \\
\hline Hyperbilirubinemia & 1 & 1 & 0 & 2 \\
\hline Thrombocytopenia & 1 & 1 & 0 & 2 \\
\hline Hypocalcemia & 1 & 0 & 0 & 1 \\
\hline Hypokalemia & 1 & 0 & 0 & 1 \\
\hline Hyponatremia & 1 & 0 & 0 & 1 \\
\hline Hypoalbuminemia & 1 & 0 & 0 & 1 \\
\hline Constipation & 1 & 0 & 0 & 1 \\
\hline Flatulence & 1 & 0 & 0 & 1 \\
\hline Cough & 1 & 0 & 0 & 1 \\
\hline Fever & 0 & 0 & 1 & 1 \\
\hline Headache & 1 & 0 & 0 & 1 \\
\hline Hypertension & 1 & 0 & 0 & 1 \\
\hline Memory impairment & 1 & 0 & 0 & 1 \\
\hline Pain (leg) & 1 & 0 & 0 & 1 \\
\hline
\end{tabular}

alkaline phosphatase and AST. The Grade 3 alkaline phosphatase elevation event occurred 1 month after treatment initiation in a patient with extensive hepatic involvement. This improved after discontinuation; however, this may have reflected a treatment response as the patient also had decreasing tumor markers with the next line of therapy.

Three of the 4 patients in Cohort 3 were evaluable. No Grade 3 or higher events occurred within this cohort. One patient was not evaluable due to death related to disease progression 18 days after starting treatment.

Seven patients were enrolled in Cohort 4. One patient experienced Grade 3 fatigue and anorexia. This patient was also noted to have Grade 2 dysgeusia that likely contributed to decreased oral intake. These side effects resolved within 2 weeks of treatment discontinuation for disease progression. Grade 3 fever was experienced by one patient in this Cohort. In addition to the above, reversible and low-Grade neurologic side effects were observed including memory impairment $(n=1)$ and headache $(n=1)$ in Cohort 1 , and dizziness $(n=3)$ and auditory changes $(n=1)$ in Cohort 4 .

There were five Grade 1-2 adverse events recorded among non-evaluable patients including a Grade 2 allergic reaction to disulfiram occurring in Cohort 1. All other events occurred in Cohort 2.

\section{Efficacy}

Response data was available for 15 of the 16 evaluable subjects (Table 4). Patient 9 died prior to first imaging 
Table 4 Best Response in all evaluable patients

\begin{tabular}{llll}
\hline ID & Cohort & Best Response $^{\mathrm{a}}$ & Days on Study \\
\hline 1 & 1 & PD & 43 \\
2 & & SD & 124 \\
3 & & PD & 32 \\
4 & 2 & PD & 40 \\
5 & & PD & 55 \\
6 & & PD & 26 \\
7 & 3 & SD & 42 \\
8 & & PD & 56 \\
10 & 4 & PD & 56 \\
11 & & SD & 109 \\
12 & & PD & 28 \\
13 & & SD & 109 \\
14 & & PD & 34 \\
15 & & PD & 43 \\
16 & & PD & 56
\end{tabular}

${ }^{\mathrm{a}} P D$ progressive disease, $N A$ not available

assessment. Eleven patients had disease progression and 4 had stable disease (mean 96 days, range 42124). One patient in Cohort 3 was characterized as having symptomatic progression without evidence of progression per RECIST and was categorized as having stable disease. No partial or complete responses were observed. One heavily pretreated patient with colorectal cancer had disease stabilization for 124 days in Cohort 1.

\section{Pharmacodynamics}

Pharmacodynamic data were available for 9 patients. Increased serum protein $S$-glutathionylation was observed in 6 patients (Fig. 1). Two of the patients had no change in serum protein $S$-glutathionylation and one patient had a decrease.

\section{Discussion}

Daily disulfiram at $250 \mathrm{mg}$ with a maximum $8 \mathrm{mg}$ of elemental copper was well-tolerated with no DLTs. Elevation of liver function tests may have been treatmentrelated. However, this population was selected for hepatic metastases. Neurologic side effects were of low grade and reversible though more common with higher doses of copper. A decline in performance status due to other factors such as anorexia, disease progression, or concomitant central nervous system disease in some patients make the exact attribution of these neurologic adverse events difficult in this small study.

Different cancers are associated with increased intratumoral copper levels or altered systemic copper distribution [48]. Copper promotes tumor progression by playing critical roles in angiogenesis and metastasis [48]. Consequently, copper-chelating agents (such as tetrathiomolibdate) have been proposed for the treatment of malignancies. However, it has been suggested that copper chelation alone is insufficient to kill malignant cells and that for cancer treatment, chelating agents should be combined with other drugs [48]. On the other hand, disulfiram-metal complexes show promising anti-cancer activity both in preclinical models and early phase clinical trials. The limited data currently available demonstrate mixed results in regard to efficacy, though an increase in survival was observed in a study of disulfiram and chemotherapy in non-small cell lung cancer [46]. Data suggest that disulfiram alone or in combination with chemotherapy or metals is safe and well-tolerated with disulfiram dosing ranging from $40 \mathrm{mg}$ three times daily to $2000 \mathrm{mg} / \mathrm{m}^{2}$.

In our study no partial or complete responses were seen. This may be due in part to inadequate drug concentrations with once daily dosing, or the fact that we enrolled heavily pretreated patients, or the small sample size of our study. Patients with solid tumors or those with metastases may not be ideal responders to disulfiram-metal combinations. Combining disulfirammetal treatment with cytotoxic chemotherapy may yield

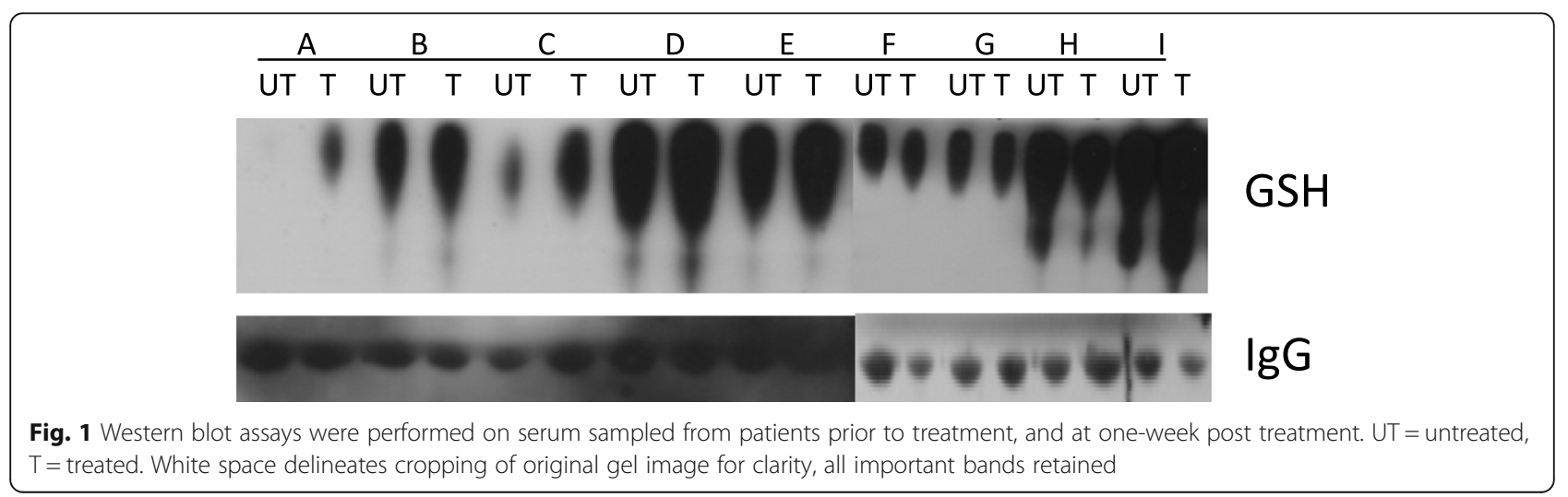


synergistic responses and remains a promising area of investigation.

There is a clear need for predictive biomarkers. Deletion p16 in B-cell ALL cells and in patient-derived xenografts may predict efficacy of disulfiram and copper [49]. Similarly, BRCA-deficient cells have demonstrated increased responses to disulfiram in in vitro models due to increased susceptibility to acetaldehyde toxicity [50]. Loss of 16q, a genetic abnormality observed in many tumor types, may increase the bioavailability of copper and therefore the potency of treatment [51].

In their study of the combination of disulfiram and zinc, Brar et al. have suggested that dithiocarbamate/ metal complexes disrupt transcription factor binding to DNA by inducing $S$-glutathionylation [11]. In addition, Paranjpe et al. have shown that disulfiram, with or without copper, induces degradation of NF- $\mathrm{B}$, and induces $S$-glutathionylation and degradation of p53 [52]. Degradation of $\mathrm{p} 53$ and NF- $\mathrm{kB}$ correlates with decreases in their specific binding to DNA, suggesting that $S$-glutathionylation inhibits the functional activity of the proteins. We therefore hypothesized that the combination of disulfiram and copper could induce protein $S$-glutathionylation in vivo. Our pharmacodynamics data show that $S$-glutathionylation of serum proteins tends to increase following treatment with disulfiram and copper. In $S$-glutathionylation, glutathione is reversibly conjugated to free thiols on protein cysteine residues forming mixed disulfide bonds [53] with resultant inhibition of protein function. Disulfiram induces $S$-glutathionylation and inactivation of proteins important for cell survival [11] including Jun, NF-kB, ATF/CREB, and other proteins involved in cell proliferation $[54,55]$. S-glutathionylation inhibits glycolysis [56] and thus may exert a negative effect on tumor metabolism. While $S$-glutathionylation of serum proteins does not necessarily imply protein $S$-glutathionylation in tumor cells, our findings suggest that such a mechanism may contribute to the antineoplastic activity of the combination. Our sample size was too small to allow correlation between $S$-glutathionylation and response. However, this will be important to investigate in future larger trials.

\section{Conclusions}

This Phase 1 trial of disulfiram in combination with up to $8 \mathrm{mg}$ of elemental copper demonstrated safety and tolerability in patients with metastatic solid tumors to the liver. While some patients had stable disease, no objective responses were observed. Given likely nonoverlapping toxicities and potential for synergy, use of disulfiram-metal combinations with cytotoxic chemotherapy is an attractive avenue of investigation which enhance efficacy. As supported by promising emerging preclinical data, application of this therapy to other disease states including hematologic malignancies in a biomarker-driven fashion may result in more significant clinical benefit [51]. The excellent safety profile of this combination together with the presence of multiple identified therapeutic targets, ease of use, drug availability, and low-cost warrant further study of disulfiram and metals in the treatment of cancer.

\section{Abbreviations}

ALT: Alanine transaminase; AST: Aspartate aminotransferase; DLT: Doselimiting toxicity; ECOG: Eastern Cooperative Oncology Group; IND: Investigational new drug; MAD: Maximum administered dose; MTD: Maximum tolerated dose

\section{Supplementary Information}

The online version contains supplementary material available at https://doi. org/10.1186/s12885-021-08242-4.

Additional file 1: Supplementary Table 1. Clinical trials investigating disulfiram in patients with solid tumors. Supplementary Table 2.

Characteristics of non-evaluable patients.

\section{Acknowledgements}

Not applicable.

\section{Authors' contributions}

KCK: Writing - original draft, writing - review and editing. KFG: Project administration, supervision, data curation. MBB: Writing - original draft. KMT: Data curation, project administration. WLA: Project administration, supervision, data curation. MCT: Data curation, formal analysis. KMK: Data curation, formal analysis. KMB: Formal analysis, investigation methodology. SSB: Project administration, supervision, data curation. KAM: Project administration, supervision, data curation. TLW: Project administration, supervision, data curation. NA: Project administration, supervision, data curation. JRW: Project administration, supervision, data curation. SS: Project administration, supervision, data curation. JHW: Project administration, supervision, data curation. TPK: Conceptualization, funding acquisition. DWS: Formal analysis. PS: Conceptualization, investigation methodology. All authors read and approved the final manuscript.

\section{Authors' information}

Not applicable.

Funding

JSK Therapeutics and the Huntsman Cancer Institute.

\section{Availability of data and materials}

The datasets used and/or analyzed during the current study are available from the corresponding author on reasonable request.

\section{Declarations}

Ethics approval and consent to participate

The study was conducted under Investigational New Drug (IND) \#100,937 and approved by the University of Utah Institutional Review Board. Informed consent was obtained from all participants. All methods were performed in accordance with the relevant guidelines and regulations.

Consent for publication

Not applicable.

\section{Competing interests}

PJS: co-founder, shareholder, and Chief Medical Officer in JSK Therapeutics. Co-founder and shareholder in Lone Star Thiotherapies. Research funding from Cantex Pharmaceuticals, Chimerix, Amgen, Aptevo, Ono, and Pfizer. Consultancy with BMS, Gilead, and Takeda. TPK: co-founder, shareholder in JSK Therapeutics, Lone Star Thiotherapies, and Cantex Pharmaceuticals. DWS: 
advisor and consultant to Janssen, Skyline Dx, GlaxoSmithKline, Legend Biotech, Amgen, and Celgene. NA: Consultant to Astellas, Astra Zeneca, Bayer, Bristol Myers Squibb, Clovis, Eisai, Eli Lilly, EMD Serono, Exelixis, Foundation Medicine, Genentech, Janssen, Merck, Nektar, Novartis, Pfizer, Pharmacyclics, and Seattle Genetics. Institutional research funding has been provided by Astra Zeneca, Bavarian Nordic, Bayer, Bristol Myers Squibb, Calithera, Celldex, Clovis, Eisai, Eli Lilly, EMD Serono, Exelixis, Genentech, Glaxo Smith Kline, Immunomedics, Janssen, Medivation, Merck, Nektar, New Link Genetics, Novartis, Pfizer, Prometheus, Rexahn, Roche, Sanofi, Seattle Genetics, Takeda, and Tracon. The remaining authors have no relevant disclosures.

\section{Author details}

'Department of Internal Medicine, University of Utah, Salt Lake City, Utah, USA. ${ }^{2}$ Division of Medical Oncology, Department of Internal Medicine, Huntsman Cancer Institute, University of Utah, Salt Lake City, Utah, USA. ${ }^{3}$ Huntsman Cancer Institute, University of Utah, Salt Lake City, Utah, USA. ${ }^{4}$ Division of Hematology and Hematologic Malignancies, Department of Internal Medicine, Huntsman Cancer Institute, University of Utah, 2000 Circle of Hope, Salt Lake City, Utah, USA. ${ }^{5}$ Pulmonary Diseases, Critical Care and Environmental Medicine, Tulane University, New Orleans, USA.

\section{Received: 16 December 2020 Accepted: 15 April 2021} Published online: 07 May 2021

\section{References}

1. Schirmer HK, Scott WW. Disulfiram and tumor inhibition. Trans Am Assoc Genitourin Surg. 1966;58:63-6.

2. Tardito S, Bassanetti I, Bignardi C, Elviri L, Tegoni M, Mucchino C, et al. Copper binding agents acting as copper ionophores lead to caspase inhibition and paraptotic cell death in human cancer cells. J Am Chem Soc. 2011;133(16):6235-42. https://doi.org/10.1021/ja109413c.

3. Viola-Rhenals M, Patel KR, Jaimes-Santamaria L, Wu G, Liu J, Dou QP. Recent advances in Antabuse (Disulfiram): the importance of its metal-binding ability to its anticancer activity. Curr Med Chem. 2018;25(4):506-24. https:// doi.org/10.2174/0929867324666171023161121

4. Morrison BW, Doudican NA, Patel KR, Orlow SJ. Disulfiram induces copperdependent stimulation of reactive oxygen species and activation of the extrinsic apoptotic pathway in melanoma. Melanoma Res. 2010;20(1):11-20. https://doi.org/10.1097/CMR.0b013e328334131d.

5. Bruning A, Kast RE. Oxidizing to death: disulfiram for cancer cell killing. Cell Cycle. 2014;13(10):1513-4. https://doi.org/10.4161/cc.28959.

6. Mankhetkorn S, Abedinzadeh Z, Houee-Levin C. Antioxidant action of sodium diethyldithiocarbamate: reaction with hydrogen peroxide and superoxide radical. Free Radic Biol Med. 1994;17(6):517-27. https://doi.org/1 0.1016/0891-5849(94)90091-4.

7. Zanocco AL, Pavez R, Videla LA, Lissi EA. Antioxidant capacity of diethyldithiocarbamate in a metal independent lipid peroxidative process. Free Radic Biol Med. 1989;7(2):151-6. https://doi.org/10.1016/0891-584 9(89)90006-3.

8. Yip NC, Fombon IS, Liu P, Brown S, Kannappan V, Armesilla AL, et al Disulfiram modulated ROS-MAPK and NFkappaB pathways and targeted breast cancer cells with cancer stem cell-like properties. Br J Cancer. 2011; 104(10):1564-74. https://doi.org/10.1038/bjc.2011.126.

9. Schreck R, Meier B, Mannel DN, Droge W, Baeuerle PA. Dithiocarbamates as potent inhibitors of nuclear factor kappa B activation in intact cells. J Exp Med. 1992;175(5):1181-94. https://doi.org/10.1084/jem.175.5.1181.

10. Li Y, Fu SY, Wang LH, Wang FY, Wang NN, Cao Q, et al. Copper improves the anti-angiogenic activity of disulfiram through the EGFR/Src/NEGF pathway in gliomas. Cancer Lett. 2015;369(1):86-96. https://doi.org/10.1016/ j.canlet.2015.07.029.

11. Brar SS, Grigg C, Wilson KS, Holder WD Jr, Dreau D, Austin C, et al. Disulfiram inhibits activating transcription factor/cyclic AMP-responsive element binding protein and human melanoma growth in a metaldependent manner in vitro, in mice and in a patient with metastatic disease. Mol Cancer Ther. 2004;3(9):1049-60.

12. Liu GY, Frank N, Bartsch H, Lin JK. Induction of apoptosis by thiuramdisulfides, the reactive metabolites of dithiocarbamates, through coordinative modulation of NFkappaB, c-fos/c-Jun, and p53 proteins. Mol Carcinog. 1998;22(4):235-46. https://doi.org/10.1002/(SICI)1098-2744 (199808)22:4<235::AID-MC5>3.0.CO;2-I.
13. Lin J, Haffner MC, Zhang Y, Lee BH, Brennen WN, Britton J, et al. Disulfiram is a DNA demethylating agent and inhibits prostate cancer cell growth. Prostate. 2011;71(4):333-43. https://doi.org/10.1002/pros.21247.

14. Chen J, Du C, Kang J, Wang J. Cu2+ is required for pyrrolidine dithiocarbamate to inhibit histone acetylation and induce human leukemia cell apoptosis. Chem Biol Interact. 2008;171(1):26-36. https://doi.org/10.101 6/j.cbi.2007.09.004

15. Lovborg H, Oberg F, Rickardson L, Gullbo J, Nygren P, Larsson R. Inhibition of proteasome activity, nuclear factor-KappaB translocation and cell survival by the antialcoholism drug disulfiram. Int J Cancer. 2006;118(6):1577-80. https://doi.org/10.1002/ijc.21534.

16. Chen D, Cui QC, Yang H, Dou QP. Disulfiram, a clinically used antialcoholism drug and copper-binding agent, induces apoptotic cell death in breast cancer cultures and xenografts via inhibition of the proteasome activity. Cancer Res. 2006;66(21):10425-33. https://doi.org/10.1158/0008-54 72.CAN-06-2126.

17. Milacic V, Chen D, Ronconi L, Landis-Piwowar KR, Fregona D, Dou QP. A novel anticancer gold(III) dithiocarbamate compound inhibits the activity of a purified 205 proteasome and 265 proteasome in human breast cancer cell cultures and xenografts. Cancer Res. 2006;66(21):10478-86. https://doi.org/1 0.1158/0008-5472.CAN-06-3017.

18. Cvek B, Milacic V, Taraba J, Dou QP. Ni(II), cu(II), and Zn(II) diethyldithiocarbamate complexes show various activities against the proteasome in breast cancer cells. J Med Chem. 2008;51(20):6256-8. https:// doi.org/10.1021/jm8007807.

19. Chen D, Peng F, Cui QC, Daniel KG, Orlu S, Liu J, et al. Inhibition of prostate cancer cellular proteasome activity by a pyrrolidine dithiocarbamate-copper complex is associated with suppression of proliferation and induction of apoptosis. Front Biosci. 2005;10(1-3):2932-9. https://doi.org/10.2741/1749.

20. Daniel KG, Chen D, Orlu S, Cui QC, Miller FR, Dou QP. Clioquinol and pyrrolidine dithiocarbamate complex with copper to form proteasome inhibitors and apoptosis inducers in human breast cancer cells. Breast Cancer Res. 2005;7(6):R897-908. https://doi.org/10.1186/bcr1322.

21. Yu Z, Wang F, Milacic V, Li X, Cui QC, Zhang B, et al. Evaluation of copperdependent proteasome-inhibitory and apoptosis-inducing activities of novel pyrrolidine dithiocarbamate analogues. Int J Mol Med. 2007;20(6):919-25.

22. Milacic V, Chen D, Giovagnini L, Diez A, Fregona D, Dou QP. Pyrrolidine dithiocarbamate-zinc(II) and -copper(II) complexes induce apoptosis in tumor cells by inhibiting the proteasomal activity. Toxicol Appl Pharmacol. 2008;231(1):24-33. https://doi.org/10.1016/j.taap.2008.03.009.

23. Marikovsky M, Nevo N, Vadai E, Harris-Cerruti C. Cu/Zn superoxide dismutase plays a role in angiogenesis. Int J Cancer. 2002;97(1):34-41. https://doi.org/10.1002/ijc.1565

24. Shian SG, Kao YR, Wu FY, Wu CW. Inhibition of invasion and angiogenesis by zinc-chelating agent disulfiram. Mol Pharmacol. 2003;64(5):1076-84. https://doi.org/10.1124/mol.64.5.1076.

25. Balakirev MY, Zimmer G. Mitochondrial injury by disulfiram: two different mechanisms of the mitochondrial permeability transition. Chem Biol Interact. 2001;138(3):299-311. https://doi.org/10.1016/S0009-2797(01)002836.

26. Cen D, Gonzalez Rl, Buckmeier JA, Kahlon RS, Tohidian NB, Meyskens FL Jr. Disulfiram induces apoptosis in human melanoma cells: a redox-related process. Mol Cancer Ther. 2002;1(3):197-204.

27. Malaguarnera L, Pilastro MR, Vicari L, Dimarco R, Manzella L, Palumbo G, et al. Pyrrolidinedithiocarbamate induces apoptosis in human acute myelogenous leukemic cells affecting NF-kappaB activity. Cancer Investig. 2005;23(5):404-12. https://doi.org/10.1081/CNV-67147.

28. Morais C, Pat B, Gobe G, Johnson DW, Healy H. Pyrrolidine dithiocarbamate exerts anti-proliferative and pro-apoptotic effects in renal cell carcinoma cell lines. Nephrol Dial Transplant. 2006;21(12):3377-88. https://doi.org/10.1093/ ndt/gfl543.

29. Cen D, Brayton D, Shahandeh B, Meyskens FL Jr, Farmer PJ. Disulfiram facilitates intracellular cu uptake and induces apoptosis in human melanoma cells. J Med Chem. 2004;47(27):6914-20. https://doi.org/10.1021/ jm049568z.

30. Saggioro D, Rigobello MP, Paloschi L, Folda A, Moggach SA, Parsons S, et al. Gold(III)-dithiocarbamato complexes induce cancer cell death triggered by thioredoxin redox system inhibition and activation of ERK pathway. Chem Biol. 2007;14(10):1128-39. https://doi.org/10.1016/j.chembiol.2007.08.016.

31. Chen SH, Lin JK, Liang YC, Pan MH, Liu SH, Lin-Shiau SY. Involvement of activating transcription factors JNK, NF-kappaB, and AP-1 in apoptosis 
induced by pyrrolidine dithiocarbamate/cu complex. Eur J Pharmacol. 2008; 594(1-3):9-17. https://doi.org/10.1016/j.ejphar.2008.07.024.

32. Sauna ZE, Shukla S, Ambudkar SV. Disulfiram, an old drug with new potential therapeutic uses for human cancers and fungal infections. Mol BioSyst. 2005;1 (2):127-34. https://doi.org/10.1039/b504392a.

33. Loo TW, Clarke DM. Blockage of drug resistance in vitro by disulfiram, a drug used to treat alcoholism. J Natl Cancer Inst. 2000;92(11):898-902. https://doi.org/10.1093/jnci/92.11.898.

34. Loo TW, Bartlett MC, Clarke DM. Disulfiram metabolites permanently inactivate the human multidrug resistance P-glycoprotein. Mol Pharm. 2004; 1(6):426-33. https://doi.org/10.1021/mp049917l.

35. Koppaka V, Thompson DC, Chen Y, Ellermann M, Nicolaou KC, Juvonen RO, et al. Aldehyde dehydrogenase inhibitors: a comprehensive review of the pharmacology, mechanism of action, substrate specificity, and clinical application. Pharmacol Rev. 2012;64(3):520-39. https://doi.org/10.1124/ pr.111.005538.

36. Wang W, McLeod HL, Cassidy J. Disulfiram-mediated inhibition of NFkappaB activity enhances cytotoxicity of 5-fluorouracil in human colorectal cancer cell lines. Int J Cancer. 2003;104(4):504-11. https://doi.org/10.1002/ ijc.10972.

37. Morais C, Gobe G, Johnson DW, Healy H. Inhibition of nuclear factor kappa $B$ transcription activity drives a synergistic effect of pyrrolidine dithiocarbamate and cisplatin for treatment of renal cell carcinoma. Apoptosis. 2010;15(4):412-25. https://doi.org/10.1007/s10495-009-0414-y.

38. Dalla Pozza E, Donadelli M, Costanzo C, Zaniboni T, Dando I, Franchini M, et al. Gemcitabine response in pancreatic adenocarcinoma cells is synergistically enhanced by dithiocarbamate derivatives. Free Radic Biol Med. 2011;50(8):926-33. https://doi.org/10.1016/j.freeradbiomed.2011.01.001.

39. Xu B, Shi P, Fombon IS, Zhang Y, Huang F, Wang W, et al. Disulfiram/copper complex activated JNK/C-Jun pathway and sensitized cytotoxicity of doxorubicin in doxorubicin resistant leukemia HL60 cells. Blood Cells Mol Dis. 2011:47(4):264-9. https://doi.org/10.1016/j.bcmd.2011.08.004.

40. Triscott J, Lee C, Hu K, Fotovati A, Berns R, Pambid M, et al. Disulfiram, a drug widely used to control alcoholism, suppresses the self-renewal of glioblastoma and over-rides resistance to temozolomide. Oncotarget. 2012; 3(10):1112-23. https://doi.org/10.18632/oncotarget.604.

41. Tahata S, Yuan B, Kikuchi H, Takagi N, Hirano T, Toyoda H. Cytotoxic effects of pyrrolidine dithiocarbamate in small-cell lung cancer cells, alone and in combination with cisplatin. Int J Oncol. 2014;45(4):1749-59. https://doi.org/1 0.3892/ijo.2014.2564.

42. Huang J, Chaudhary R, Cohen AL, Fink K, Goldlust S, Boockvar J, et al. A multicenter phase II study of temozolomide plus disulfiram and copper for recurrent temozolomide-resistant glioblastoma. J Neuro-Oncol. 2019;142(3): 537-44. https://doi.org/10.1007/s11060-019-03125-y.

43. Schweizer MT, Lin J, Blackford A, Bardia A, King S, Armstrong AJ, et al. Pharmacodynamic study of disulfiram in men with non-metastatic recurrent prostate cancer. Prostate Cancer Prostatic Dis. 2013;16(4):357-61. https://doi. org/10.1038/pcan.2013.28.

44. Grossmann KF, Terrazas M, Khong HT, Akerley W, Kosak K, Boucher K, et al. Abstract LB-175: Phase II study of disulfiram and chelated Zn for the treatment of disseminated metastatic melanoma. Cancer Res. 2013;73(8 Supplement):LB-175.

45. Verma S, Stewart DJ, Maroun JA, Nair RC. A randomized phase II study of cisplatin alone versus cisplatin plus disulfiram. Am J Clin Oncol. 1990;13(2): 119-24. https://doi.org/10.1097/00000421-199004000-00007.

46. Nechushtan H, Hamamreh Y, Nidal S, Gotfried M, Baron A, Shalev YI, et al. A phase $\mathrm{Ib}$ trial assessing the addition of disulfiram to chemotherapy for the treatment of metastatic non-small cell lung cancer. Oncologist. 2015;20(4): 366-7. https://doi.org/10.1634/theoncologist.2014-0424.

47. de Ridder J, de Wilt JH, Simmer F, Overbeek L, Lemmens V, Nagtegaal I. Incidence and origin of histologically confirmed liver metastases: an explorative case-study of 23,154 patients. Oncotarget. 2016;7(34):55368-76. https://doi.org/10.18632/oncotarget.10552

48. Denoyer D, E S, Cater MA. Targeting copper in cancer therapy: 'Copper that Cancer'. Metallomics. 2015;7(11):1459-76. Masaldan S, La Fontain.

49. Deng M, Jiang Z, Li Y, Zhou Y, Li J, Wang X, et al. Effective elimination of adult B-lineage acute lymphoblastic leukemia by disulfiram/copper complex in vitro and in vivo in patient-derived xenograft models. Oncotarget. 2016; 7(50):82200-12. https://doi.org/10.18632/oncotarget.9413.

50. Tacconi EM, Lai X, Folio C, Porru M, Zonderland G, Badie S, et al. BRCA1 and BRCA2 tumor suppressors protect against endogenous acetaldehyde toxicity. EMBO Mol Med. 2017;9(10):1398-414. https://doi.org/10.15252/ emmm.201607446.

51. Corsello SM, Nagari RT, Spangler RD, Rossen J, Kocak M, Bryan JG, et al. Discovering the anticancer potential of non-oncology drugs by systematic viability profiling. Nature Cancer. 2020;1(2):235-48. https://doi.org/10.1038/ s43018-019-0018-6.

52. Paranjpe A, Srivenugopal KS. Degradation of NF-kappaB, p53 and other regulatory redox-sensitive proteins by thiol-conjugating and -nitrosylating drugs in human tumor cells. Carcinogenesis. 2013;34(5):990-1000. https:// doi.org/10.1093/carcin/bgt032.

53. Ghezzi P. Regulation of protein function by glutathionylation. Free Radic Res. 2005;39(6):573-80. https://doi.org/10.1080/10715760500072172.

54. Ghezzi P, Bonetto V, Fratelli M. Thiol-disulfide balance: from the concept of oxidative stress to that of redox regulation. Antioxid Redox Signal. 2005;7(78):964-72. https://doi.org/10.1089/ars.2005.7.964

55. Shelton MD, Chock PB, Mieyal JJ. Glutaredoxin: role in reversible protein sglutathionylation and regulation of redox signal transduction and protein translocation. Antioxid Redox Signal. 2005;7(3-4):348-66. https://doi.org/10.1 089/ars.2005.7.348

56. Cross JV, Templeton DJ. Oxidative stress inhibits MEKK1 by site-specific glutathionylation in the ATP-binding domain. Biochem J. 2004;381(Pt 3): 675-83. https://doi.org/10.1042/BJ20040591.

\section{Publisher's Note}

Springer Nature remains neutral with regard to jurisdictional claims in published maps and institutional affiliations.
Ready to submit your research? Choose BMC and benefit from:

- fast, convenient online submission

- thorough peer review by experienced researchers in your field

- rapid publication on acceptance

- support for research data, including large and complex data types

- gold Open Access which fosters wider collaboration and increased citations

- maximum visibility for your research: over $100 \mathrm{M}$ website views per year

At BMC, research is always in progress.

Learn more biomedcentral.com/submissions 